IZA DP No. 6725

Cheating in the Workplace: An Experimental Study of the Impact of Bonuses and Productivity

David Gill

Victoria Prowse

Michael Vlassopoulos

July 2012 


\title{
Cheating in the Workplace: An Experimental Study of the Impact of Bonuses and Productivity
}

\author{
David Gill \\ Oxford University \\ Victoria Prowse \\ Cornell University \\ and IZA \\ Michael Vlassopoulos \\ University of Southampton
}
Discussion Paper No. 6725
July 2012

IZA
P.O. Box 7240
53072 Bonn
Germany

Phone: +49-228-3894-0

Fax: +49-228-3894-180

E-mail: iza@iza.org

\begin{abstract}
Any opinions expressed here are those of the author(s) and not those of IZA. Research published in this series may include views on policy, but the institute itself takes no institutional policy positions.

The Institute for the Study of Labor (IZA) in Bonn is a local and virtual international research center and a place of communication between science, politics and business. IZA is an independent nonprofit organization supported by Deutsche Post Foundation. The center is associated with the University of Bonn and offers a stimulating research environment through its international network, workshops and conferences, data service, project support, research visits and doctoral program. IZA engages in (i) original and internationally competitive research in all fields of labor economics, (ii) development of policy concepts, and (iii) dissemination of research results and concepts to the interested public.
\end{abstract}

IZA Discussion Papers often represent preliminary work and are circulated to encourage discussion. Citation of such a paper should account for its provisional character. A revised version may be available directly from the author. 


\section{ABSTRACT}

\section{Cheating in the Workplace: An Experimental Study of the Impact of Bonuses and Productivity}

We use an online real-effort experiment to investigate how bonus-based pay and worker productivity interact with workplace cheating. Firms often use bonus-based compensation plans, such as group bonuses and firm-wide profit sharing, that induce considerable uncertainty in how much workers are paid. Exposing workers to a compensation scheme based on random bonuses makes them cheat more but has no effect on their productivity. We also find that more productive workers behave more dishonestly. We explain how these results suggest that workers' cheating behavior responds to the perceived fairness of their employer's compensation scheme.

JEL Classification: C91, J33

Keywords: bonus, compensation, cheating, dishonesty, lying, employee crime, productivity, slider task, real effort, experiment

Corresponding author:

Victoria Prowse

Department of Economics

264 Ives Hall

Cornell University

Ithaca, NY 14853

USA

E-mail: prowse@cornell.edu

\footnotetext{
* We thank Leigh Wedenoja and Jiadi Yao for excellent research assistance. Funding for this project was provided by the Economic and Social Research Council and a Zvi Meitar/Vice-Chancellor Oxford University Social Sciences Research Grant.
} 


\section{Introduction}

A vast body of evidence shows that cheating, fraud and crime are pervasive in the workplace. ${ }^{1}$ In this paper, we investigate how pay structures and worker productivity interact with workplace cheating. We focus on two specific questions. First, how does the uncertainty inherent in bonusbased compensation schemes influence the amount of employee dishonesty? Second, is there a link between workers' productivity and how much they cheat?

\subsection{Summary of experimental design and findings}

To study these questions, we conducted an online experiment using the computerized real-effort 'slider task' (Gill and Prowse, 2012) that involves moving sliders across a screen. To start with, subjects were paid to complete a certain amount of the task. In the control, the subjects were paid a fixed amount, either $£ 2$ or $£ 8$, for completing the work. In the bonus treatment, subjects were paid $£ 2$ for sure for completing the work, but with $50 \%$ probability were also paid a bonus of an additional $£ 6$. Notice that the two-point distribution of remuneration was therefore held constant across the control and the bonus treatment. In a subsequent stage, all subjects worked under a common piece rate, and simultaneously were given an opportunity to cheat: we asked the subjects to report the last digit of their best friend's phone number and paid them an amount in pounds equal to the number that they reported. The design allows us to identify the causal effect of the random component of bonuses on later cheating and productivity, and also to determine whether there is a relationship between working harder and cheating more. The experimental nature of our design gives us the control necessary to identify cleanly causal effects and to measure accurately changes in productivity and cheating.

We find three main results. First, the use of random bonuses increases cheating but has no effect on productivity. Subjects who have been exposed to the bonus-based compensation scheme are more likely to behave dishonestly by inflating the number that they report: using random bonuses increases the average report by $5 \%$ and increases the proportion of subjects reporting a 7 or higher by $9 \%$. This result suggests that the uncertainty inherent in bonus-based compensation may have important unintended side effects that firms ought to take into account when designing their human resource policies. Second, receiving a random bonus has no effect on cheating or productivity: within the subjects exposed to bonus-based system, those who received the bonus cheat to the same extent and work as hard as those subjects who did not receive the bonus. Third, across our whole sample more productive subjects also cheat more: our regression results indicate that the hardest-working subjects report a number $22 \%$ higher than that reported by the least hard-working, while the most productive are $43 \%$ more likely to report a 7 or higher. Although not the main focus of our paper, we also find that males cheat more: on average males report a number $7 \%$ higher than that reported by females. ${ }^{2}$

\footnotetext{
${ }^{1}$ We survey some of the evidence in Section 1.2 .

${ }^{2}$ Dreber and Johannesson (2008), Conrads et al. (2011) and Houser et al. (2011) also find that males behave more dishonestly.
} 


\subsection{Relevance of our set-up to labor markets}

Our set-up is relevant to labor markets for three main reasons: first, workers have many opportunities to cheat their employers; second, our methodology for measuring cheating allows what we call 'soft' as well as 'hard' cheating, both of which are important in labor markets; and third, firms commonly use bonus-based compensation that involves an important random component.

First, employee cheating and crime is an enormous and pervasive problem for firms and the economy. The Association of Certified Examiners estimates that the typical firm loses about 5\% of revenues to occupational fraud, which translates into a loss of $\$ 3.5$ trillion at the global level (ACFE, 2012). Dickens et al. (1989) survey the evidence, reporting that $5 \%$ to $30 \%$ of business failures in the US result from the cost of employee theft, while finding "overwhelming empirical evidence that firms expend considerable resources trying to detect employee malfeasance." Jacob and Levitt (2003) find evidence of teachers cheating on standardized test scores in about $5 \%$ of classrooms annually. Employees can cheat their employers in a wide variety of ways. Grover (1993) summarizes many of the ways in which employees can lie in their reports (self-reporting of hours worked, for instance, is common in professional services such as auditing, consultancy and the law). ${ }^{3}$ Other forms of cheating include: payroll fraud; falsifying revenue figures; false or inflated invoicing; false expense claims; cash skimming; check tampering; theft of inventory or telephone services; customer identity theft; and theft of intellectual property.

Second, our methodology for measuring cheating provides an opportunity for what we call 'soft' and 'hard' cheating. By hard cheating we mean a subject who cheats knowingly, that is a subject who either (i) knows the last digit of her best friend's phone number but reports something higher or (ii) does not know the last digit but reports a number instead of selecting "don't know". 4 By soft cheating we mean a subject who subconsciously deceives herself in a favorable way about either (i) the identity of her best friend or (ii) the last digit of her best friend's phone number. The scope for soft cheating introduced by our novel design mimics the many opportunities for soft cheating and self-deception in the workplace that might impact the employer. Workers can deceive themselves on a number of dimensions, including for example:

\footnotetext{
3 "People have ample opportunity to either lie or tell the truth in the course of their work. Workers continually report their behavior and give information to peers, superordinates, and others, in written form, orally, and nonverbally. The truck driver records the number of hours on the road, the nurse charts vital signs, the certified public accountant states what has been audited, and the forester reports a tree census. Organizations generally rely on these reports to be honest. However, each of these individuals may have reasons to lie. The truck driver returns home sooner if he says he drove the speed limit when in fact he exceeded it; the nurse may not have time to actually observe vital signs that must be recorded; CPA's may gain partner status by exaggerating their work quantity; and the forester may misreport the tree census to prevent deforestation." (Grover, 1993, p. 478)

${ }^{4}$ Our methodology for measuring cheating is related to a recent wave of experimental studies that use a report of a privately-known outcome as an indicator of cheating or dishonesty. These papers use a 'hard' form of cheating or deception, where subjects report the outcome of a coin flip (Bucciol and Piovesan, 2011; Houser et al., 2011; Abeler et al., 2012), a die roll (Fischbacher and Heusi, 2008; Lammers et al., 2010; Conrads et al., 2011; Fischbacher and Utikal, 2011; Hao and Houser, 2011; Shalvi et al., 2011; Suri et al., 2011; Cojoc and Stoian, 2012; Lewis et al., 2012; Shalvi et al., forthcoming) or some other random variable (Coricelli et al., 2010; Eisenkopf et al., 2011). Some studies ask subjects to report their score on a task (e.g., Mazar et al., 2008; Cadsby et al., 2010; Schwieren and Weichselbaumer, 2010). There is also a literature on strategic sender-receiver games in which a sender can report the outcome of a random variable truthfully or lie (e.g., Charness and Garoupa, 2000; Lundquist et al., 2009; Wang et al., 2010), and on lying in games more generally (e.g., Croson et al., 2003; Gneezy, 2005; Charness and Dufwenberg, 2006).
} 
their personal contribution to team success (especially if they are a team leader deciding on individual bonuses); their perception of the quality of junior colleagues (who might not be promoted) or job candidates who might become future competitors (who might not be hired); the extent to which double-billing of time can be justified in professions where clients are billed for self-reported and unverifiable hours; whether they are ill enough to justify taking a paid sick day; and whether it is justified to take office equipment for personal use and make personal phone calls at work.

Third, firms often use bonus-based compensation plans that, from the perspective of the worker, contain a component that is unrelated to individual performance, but instead depends on factors that are beyond the worker's control - it is as good as random. Compensation based on the performance of the entire firm or a subgroup of employees is one source of such uncertainty. Examples include discretionary group bonuses, stock options and firm-wide profit-sharing plans. The use of stock option plans for non-executive employees is widespread and growing (Core and Guay, 2001), and non-executives receive over $60 \%$ of stock options granted by value (Oyer and Schaefer, 2005). For executives, too, stock options are becoming a more important part of total pay (Hall and Liebman, 1998), and even though CEOs impact firm performance directly, luck also plays an important role in how they are paid. ${ }^{5}$ Group bonuses, where individuals share a bonus based on their group's performance, are also common, especially in financial services (see Hansen, 1997, for a case study), and some successful firms make extensive use of profitsharing. ${ }^{6}$ Even when bonuses are based on individual performance, randomness can play an important role due to measurement error when evaluating output, especially when evaluations are subjective, and because the underlying process that translates worker input into measurable output is stochastic. ${ }^{7}$ Winning a tournament is essentially equivalent to being paid a bonus, and a large literature looks at the design of optimal tournaments in the presence of such noise (e.g., Lazear and Rosen, 1981).

\subsection{Novelty and interpretation of our results}

Despite their importance, employee cheating and crime have not received much attention by economists, and their determinants are not well understood. Our paper contributes to a small yet growing literature that examines the interaction between various compensation schemes and cheating in the workplace. Burns and Kedia (2006) and Efendi et al. (2007) find a positive

\footnotetext{
${ }^{5}$ Bertrand and Mullainathan (2001) find that CEO pay responds as much to luck, defined as observable shocks to performance beyond the firm's control, as it does to performance that is under the firm's control, and that luck affects salaries and bonuses as well as grants of stock options. One justification is that firms might want to link CEO compensation to the value of outside opportunities (Oyer, 2004).

${ }^{6}$ Knez and Simester (2001) provide a brief survey and a case study of a Continental Airlines bonus scheme for its 35,000 employees based on a firm-wide performance target; see also Bhattacherjee (2005) for a case study of a bonus scheme based on a firm-wide productivity target for the 15,000 employees of the Indian firm ITC Limited that makes up about $6 \%$ of pay on average.

${ }^{7}$ Moers (2005) uses administrative data to show how multiple performance measures and subjective evaluation make it difficult to differentiate among subordinates; see also Kaur et al. (2011, p. 29-30) for an interesting case study of randomness due to variation in the quality of equipment in an Indian call center, but there are many other sources of noise, e.g., luck in whether an important client signs a contract.
} 
relationship between CEO compensation based on stock options and financial misreporting. Curry and Mongrain (2009) and Gilpatric (2011) study theoretically the incentives to cheat in a rank-order tournament, where cheating increases both output and the probability of failing an audit. Experimental subjects have been found to cheat more when competing (Schwieren and Weichselbaumer, 2010) or when paid for reaching a target (Cadsby et al., 2010), compared to when they are paid piece-rate; and subjects report higher die rolls when paid in teams of two and share the proceeds (Conrads et al., 2011). Finally, Waller and Bishop (1990) and Chow et al. (1994) consider experimentally how different pay schemes affect subordinate managers' communication of private information. However, none of these papers examines the influence of bonuses on subsequent productivity and cheating behavior. Furthermore, to the best of our knowledge we are the first to analyze whether a link exists between productivity in a work task and cheating behavior. ${ }^{8}$

A plausible interpretation of our finding that the level of cheating depends on whether subjects were exposed to the bonus treatment, but not on whether they actually received the bonus, is that subjects perceive exposure to the random bonus as unfair, but are not influenced by outcomes per se in their perceptions of fairness. Being subject to an unfair payment mechanism provides a moral justification for negative reciprocity in the form of more dishonesty. This interpretation is broadly consistent with existing notions of procedural fairness and with a compelling body of evidence, from both laboratory experiments and field data, that workers respond negatively to unfair treatment and bad intentions. Under Trautmann (2009)'s concept of process fairness, the outcome generating process rather than the actual outcomes influences fairness perceptions, while Konow (2003, p. 1230)'s survey notes that "some argue that procedural justice is valued for itself, independent of outcomes." Charness and Levine (2007) find experimentally that worker punishment of an employer is much more sensitive to the component of wages that is under their employer's control than it is to the component due to luck, concluding that intentions matter much more than outcomes, while Houser et al. (2011) find that cheating following a dictator game is higher when recipients report that they have been treated unfairly, but fail to uncover any link between income and cheating at a later stage. Evidence from the field also backs up the idea that fairness perceptions influence employee cheating: Greenberg (1990) finds that employee theft increases when a pay cut in manufacturing plants is perceived as unfair; Nagin et al. (2002) find that call center workers who feel well treated cheat their employer less; while Chen and Sandino (forthcoming) find that employee theft decreases when wages rise relative to other comparable retail stores. ${ }^{9}$

Our result that more productive workers also cheat more might be viewed as surprising: one might expect harder workers to be more honest as well. Indeed, Eisenberger and Shank

\footnotetext{
${ }^{8}$ In a setting where subjects were able to cheat to help them solve mazes and in reporting how many were solved, Schwieren and Weichselbaumer (2010) find that subjects who solved few mazes increased the amount they cheated when they competed instead of being paid piece-rate, while those who solved many mazes did not. There is also some evidence that student ability, as measured by SAT scores or grade point averages, is negatively correlated with academic dishonesty (e.g., Abdolmohammadi and Baker, 2007).

${ }^{9}$ See also Evans III et al. (2001), Zhang (2008) and Matuszewski (2010) for a link between fairness and honesty in managerial reporting.
} 
(1985) find that subjects with a strong survey-measured work ethic resisted for longer before taking an opportunity to cheat. On the other hand, people who are more strongly motivated by money might work harder in order to earn more and be more inclined to take advantage of opportunities to cheat for personal gain. Working hard on the real-effort task might also deplete subjects' ability to withstand the temptation to cheat: Mead et al. (2009) and Gino et al. (2011) find that subjects whose self-control was depleted by being forced to undertake an onerous task cheated more than subjects made to undertake a less onerous task. Another possibility is that the subjects who worked harder felt that they deserved more for their labor. If the piece-rate wage was felt to be insufficient or unfairly low, this could have led to the more productive subjects convincing themselves that more cheating was justified. Such perceptions of unfairness would imply that low-wage or exploitative firms should be particulary wary of fraudulent behavior from their higher-productivity workers.

\subsection{Plan of the paper}

Section 2 describes the experimental design. Section 3 presents the empirical analysis and the results. Section 4 concludes. Appendix A provides the experimental instructions and Appendix B provides robustness checks.

\section{Experimental design}

We ran an online experiment during a two-week period in May 2011. To recruit subjects we sent email announcements to students at the University of Southampton. During the two-week period, 641 subjects completed the experiment at a time and location of their choosing. ${ }^{10}$ The experiment lasted 20 to 25 minutes and had to be completed in one go. The subjects were informed that they would be paid $£ 3$ for completing the experiment, on top of any money that they earned during the experiment (all payments were in pounds Sterling). The average total payment to the subjects who completed the experiment was £19.32. At the end of the experiment, we asked the subjects to report their gender. We paid the subjects privately in cash on two pre-advertised dates. The experiment was implemented using the Django open-source web application framework, which is written in Python. Appendix A provides the experimental instructions.

\subsection{The slider task}

We used the computerized real-effort 'slider task', which was first developed by Gill and Prowse (2012). ${ }^{11}$ The slider task consists of a screen displaying a large number of sliders (as described

\footnotetext{
${ }^{10}$ All those who expressed an interest were given log in details and were able to participate. 683 subjects logged in, of which 42 failed to complete the experiment. Footnote 13 provides evidence that attrition was not related to the allocation to the different experimental conditions.

${ }^{11}$ Gill and Prowse (2011b) provide details of how to implement the task, which has been used by Hetzel (2010), Bonein and Denant-Boemont (2011), Cettolin and Riedl (2011), Eacret et al. (2011), Gill and Prowse (2011a), Hammermann et al. (2011), Riener and Wiederhold (2011), Djawadi and Fahr (2012) and Monahan (2012).
} 
below, the number of sliders and the time allotted to the task varied across the stages of the experiment). Figure 1 shows a schematic representation of a single slider. Each slider is initially positioned at 0, as shown in Figure 1(a). By using her mouse or touchpad, the subject can position each slider at any integer location between 0 and 100 inclusive. $^{12}$ Each slider can be readjusted an unlimited number of times during the time allotted to the task, and the current position of each slider is displayed to the right of the slider. In this experiment, subjects received 2 points for each slider positioned at exactly 50 and 1 point for each slider positioned at exactly 49 or 51 (the points were deducted if a subject moved a slider away from a scoring position). Figure 1(b) shows a slider positioned at exactly 50, worth 2 points.

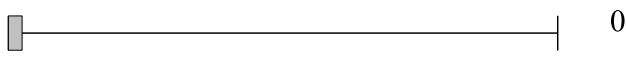

(a) Initial position.

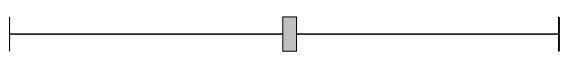

50

(b) Positioned at 50 .

Figure 1: Schematic representation of a slider.

Figure 2 shows a screen of sliders as seen by the subjects. In this example, the subject has positioned one slider at 50 and one at 49 , giving a points score of 3 . As the task proceeds, the screen displays the subject's current points score and the amount of time remaining. The slider task involves little randomness and the subject's points score gives a finely gradated measure of performance or work output, which we term 'productivity'.

\subsection{Stage 1: Practice}

In the first of the three stages, subjects were given two minutes to practice the slider task (with 102 sliders) and become familiar with it. This stage was not compensated.

\subsection{Stage 2: Control and bonus treatment}

In the second stage, subjects were given ten minutes to achieve a points score of 40 in the slider task (again with 102 sliders). We chose a long time limit to give the subjects more than ample time to achieve the required score, but subjects were aware that as soon as they reached a points score of 40 they would move on to the third and final stage and that if they did not achieve the score they would exit the experiment. Our experimental conditions varied how the subjects were compensated for completing the stage.

In the 'Control' condition (C), the subjects were paid a fixed pre-announced amount for completing the stage. The control subjects were split into two subgroups: in 'Control 1' (C1) subjects were paid $£ 2$ for completing the stage; in 'Control 2' (C2) subjects were paid $£ 8$ for completing the stage. In the 'Treatment' condition (T), subjects were told that they would be paid $£ 2$ for completing the stage, and that there was a $50 \%$ chance they would earn a bonus of an additional $£ 6$ for completing stage 2 , in which case they would be paid a total of $£ 8$ for

\footnotetext{
${ }^{12}$ Keyboards were disabled to prevent the subjects from using the arrow keys to position the sliders.
} 
You will be paid 5 pence for every point you score. You will be paid an additional amount in pounds equal to your report of the last digit of your best friend's phone number.

You will receive 2 points for each slider that you position at exactly 50 . You will receive 1 point for each slider that you position at exactly 49 or 51 .

Current points score: 3

Current report of last digit of best friend's phone number:4

Current total payment for stage 3 : $£ 4.15$

Please report the last digit of your best friend's phone number below. If you make a mistake, you can change the report during the 5 minutes for this stage. 4
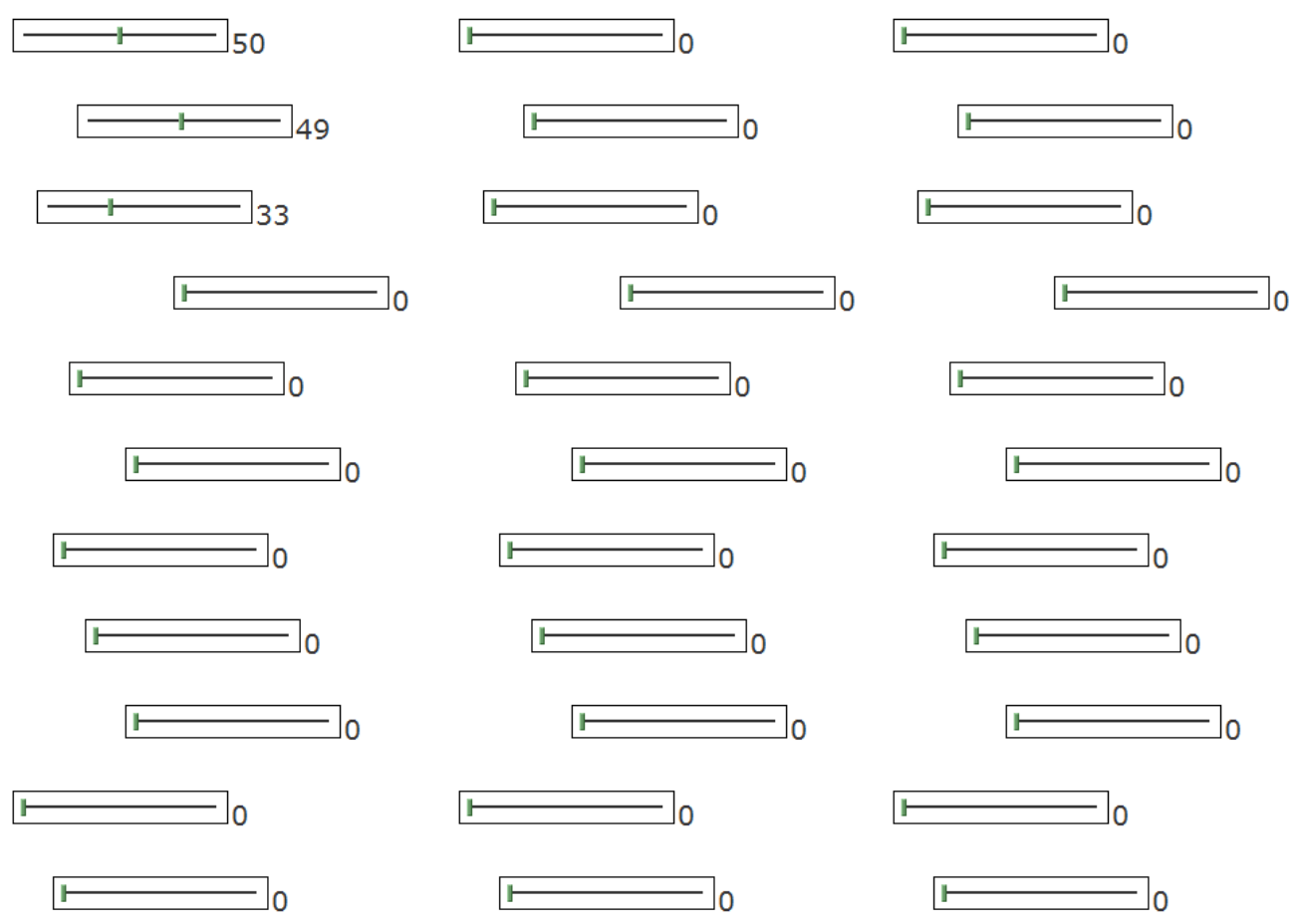

Figure 2: Screenshot of Stage 3.

Note: Not all the sliders are displayed: the subject can scroll down to see more sliders.

completing the stage. The treated subjects were informed that a random number generator would decide randomly whether or not they had earned the bonus, and that they would find out the outcome after completing the stage. 'Treatment 1' (T1) refers to the subgroup of treated subjects who did not receive the bonus, and who were thus paid $£ 2$ for completing the stage. 'Treatment 2' (T2) refers to the subgroup of treated subjects who did receive the bonus, and who were thus paid a total of $£ 8$ for completing the stage. Subjects were randomly allocated to $\mathrm{C} 1, \mathrm{C} 2$, $\mathrm{T} 1$ or $\mathrm{T} 2$ with equal probability. ${ }^{13}$

To summarize, we have a $2(£ 2$ or $£ 8) \times 2$ (fixed payment or bonus) between-subjects design.

\footnotetext{
${ }^{13}$ When subjects logged in to start the experiment, they were randomly allocated to $\mathrm{C} 1, \mathrm{C} 2$ or $\mathrm{T}$, with $25 \%$ probability, $25 \%$ probability and $50 \%$ probability respectively. After completing stage 2, the subjects in T were randomly allocated to $\mathrm{T} 1$ or T2 with equal probability. Of the 641 subjects who completed the experiment, 152 were in $\mathrm{C} 1,183$ in $\mathrm{C} 2,164$ in $\mathrm{T} 1$ and 142 in $\mathrm{T} 2$. Of the 42 subjects who logged in but failed to complete the experiment, 11 dropped out during the practice stage before they were given any information about their payment scheme. Of the 31 who dropped out after the practice stage, 7 were in C1, 6 in C2 and 18 in $\mathrm{T}$ (16 of the 18 dropped out before discovering whether they had earned the bonus or not). The attrition rate in $\mathrm{T}$ was not significantly different to that in $\mathrm{C}$ (a t-test gives a 2 -sided $p=0.265$ for the null that the attrition rates were the same), and within $\mathrm{C}$ the attrition rate in $\mathrm{C} 1$ was not significantly different to that in $\mathrm{C} 2(2$-sided $p=0.554)$.
} 
In $\mathrm{C} 1$ the subjects earned $£ 2$ for sure. In C2 they earned $£ 8$ for sure. In T1 they earned $£ 2$, but failed to receive a random bonus of $£ 6$. In $\mathrm{T} 2$ they earned $£ 8$, including a random bonus of $£ 6$. The design allows us to identify the causal effects of the random bonus: in Section 3.1 we look at the causal effect of the bonus treatment on later cheating and productivity in stage 3 , holding remuneration constant; in Section 3.2 we look at the causal effect of receiving the bonus on cheating and productivity.

\subsection{Stage 3: Cheating and productivity}

The third stage is designed to measure cheating and productivity. Subjects were given five minutes to work on the slider task (now with 201 sliders), and were paid $£ 0.05$ for every point they scored. In addition, we asked the subjects to report the last digit of their best friend's phone number and told them that they would be paid an amount in pounds equal to the number that they reported (we also gave them the option of reporting "don't know", which paid nothing). The subjects were informed that they could report the number at any time during the five minutes, that they could change their report if they made a mistake, and that the report at the end of the five minutes would determine payoffs. Figure 2 provides a screenshot of this stage.

Asking the subjects to report the last digit of their best friend's number introduces an opportunity for the subjects to cheat. By reporting a value higher than the true one, the subjects could raise their payoff without any possibility of detection. As discussed in Section 1.2, this aspect of the experimental design provides opportunities for both 'soft' and 'hard' cheating, and in so doing mimics the nature of many real-world cheating opportunities. Although we do not know the exact distribution of the last digit of people's phone numbers, we can compare the average number reported by subjects who were in different control and treatment conditions in stage 2 to detect differences in cheating. Given the subjects have no compelling incentive to underreport, any increase in the average report can reasonably be interpreted as an increase in cheating. ${ }^{14}$

\section{Results}

We split our analysis into three parts. First, we look at the causal effect of the bonus treatment on later cheating and productivity. Second, we consider the causal effect of being paid a random bonus on cheating and productivity. Finally, we see whether there is a relationship between cheating and productivity in stage 3 .

\footnotetext{
${ }^{14}$ It is possible that some subjects underreported high numbers in order to avoid any suspicion of cheating. In common with experiments which identify cheating using reports of random outcomes such as coin flips or die rolls where the underlying distribution is known, we cannot identify such behavior, but we find it unlikely that it played an important role in our experiment.
} 


\subsection{Effect of bonus treatment on cheating and productivity}

In this section, we want to discover whether subjects exposed to the random bonus treatment $\mathrm{T}$ change their behavior, compared to subjects in the control C. Recall that the comparison holds remuneration constant, as subjects in $\mathrm{C} 1$ are paid the same as in $\mathrm{T} 1$ (£2) while those in $\mathrm{C} 2$ are paid the same as in T2 (£8). To identify the causal effect of using random bonuses in stage 2 on cheating and productivity in stage 3 , we regress three outcomes of interest on a dummy for the bonus treatment, namely: (i) the report of the last digit of each subject's best friend's phone number; (ii) an indicator of the report being greater than or equal to 7; and (iii) each subject's points score in the slider task. In each case, we run the regression with and without a male control.

\begin{tabular}{|c|c|c|c|c|c|c|}
\hline & \multicolumn{2}{|c|}{$\begin{array}{l}\text { Reported } \\
\text { number }\end{array}$} & \multicolumn{2}{|c|}{$\begin{array}{l}\text { Proportion of } \\
\text { reports } \geq 7\end{array}$} & \multicolumn{2}{|c|}{$\begin{array}{l}\text { Points score in } \\
\text { slider task }\end{array}$} \\
\hline & $(1)$ & (2) & (3) & (4) & $(5)$ & $(6)$ \\
\hline $\begin{array}{c}\text { Treated } \\
\quad(\mathrm{T})\end{array}$ & $\begin{array}{l}0.353^{*} \\
{[0.192]} \\
(0.066)\end{array}$ & $\begin{array}{l}0.362^{*} \\
{[0.190]} \\
(0.057)\end{array}$ & $\begin{array}{l}0.068^{*} \\
{[0.035]} \\
(0.052)\end{array}$ & $\begin{array}{l}0.069^{* *} \\
{[0.035]} \\
(0.045)\end{array}$ & $\begin{array}{l}0.060 \\
{[1.663]} \\
(0.971)\end{array}$ & $\begin{array}{l}0.068 \\
{[1.642]} \\
(0.967)\end{array}$ \\
\hline Male & $\begin{array}{l}- \\
- \\
-\end{array}$ & $\begin{array}{l}0.537^{* * *} \\
{[0.195]} \\
(0.006)\end{array}$ & $\begin{array}{l}- \\
- \\
-\end{array}$ & $\begin{array}{l}0.100^{* * *} \\
{[0.035]} \\
(0.005)\end{array}$ & $\begin{array}{l}- \\
- \\
-\end{array}$ & $\begin{array}{l}6.980^{* * *} \\
{[1.640]} \\
(0.000)\end{array}$ \\
\hline Intercept & $\begin{array}{l}7.324^{* * *} \\
{[0.141]} \\
(0.000)\end{array}$ & $\begin{array}{l}7.022^{* * *} \\
{[0.181]} \\
(0.000)\end{array}$ & $\begin{array}{l}0.739 \text { *** } \\
{[0.025]} \\
(0.000)\end{array}$ & $\begin{array}{l}0.682^{\text {*** }} \\
{[0.034]} \\
(0.000)\end{array}$ & $\begin{array}{c}89.457^{\text {*** }} \\
{[1.216]} \\
(0.000)\end{array}$ & $\begin{array}{c}85.645^{* * *} \\
{[1.424]} \\
(0.000)\end{array}$ \\
\hline Obs. & 582 & 582 & 582 & 582 & 641 & 641 \\
\hline
\end{tabular}

Notes: (i) ${ }^{* * *}$ and ${ }^{* * *}$ denote, respectively, significance at the $10 \%, 5 \%$ and $1 \%$ levels. Heteroskedasticityrobust standard errors are in brackets. 2-sided $p$-values are in parentheses. (ii) We weight the data to allow for the fact that the ratio of subjects in $\mathrm{C} 1$ to $\mathrm{C} 2$ is not exactly the same as the ratio of subjects in T1 to T2 (see footnote 13). Table 4 in Appendix B shows that our results are robust to using the unweighted data. (iii) The first four columns include only the 582 subjects who reported a number. Table 5 in Appendix B shows that our results are robust to including all 641 subjects who completed the experiment, and so using money earned from the report as the dependent variable rather than the report itself. The effects are slightly larger in magnitude, but not quite as precisely estimated.

Table 1: Effect of bonus treatment: OLS regressions.

Table 1 shows that the bonus treatment induces more cheating but has no effect on productivity: subjects who have been exposed to the bonus treatment report significantly higher numbers on average (columns 1-2; 2-sided $p=0.057$ with a male control) and are significantly more likely to report a number greater than or equal to 7 (columns 3-4; 2-sided $p=0.045$ with a male control), but do not work significantly harder (columns 5-6; 2-sided $p=0.967$ with a male control). Using random bonuses increases the average report by $5 \%$ and increases the proportion 
of subjects reporting a 7 or higher by $9 \%$, but the increase in the average points score is less than $0.1 \%$ and not significant. ${ }^{15,16}$ In the light of evidence that firms often use bonus-based compensation that includes an important random component (see Section 1.2), this suggests that firms ought to take into account possible unintended consequences for worker honesty when designing bonus-based pay structures.

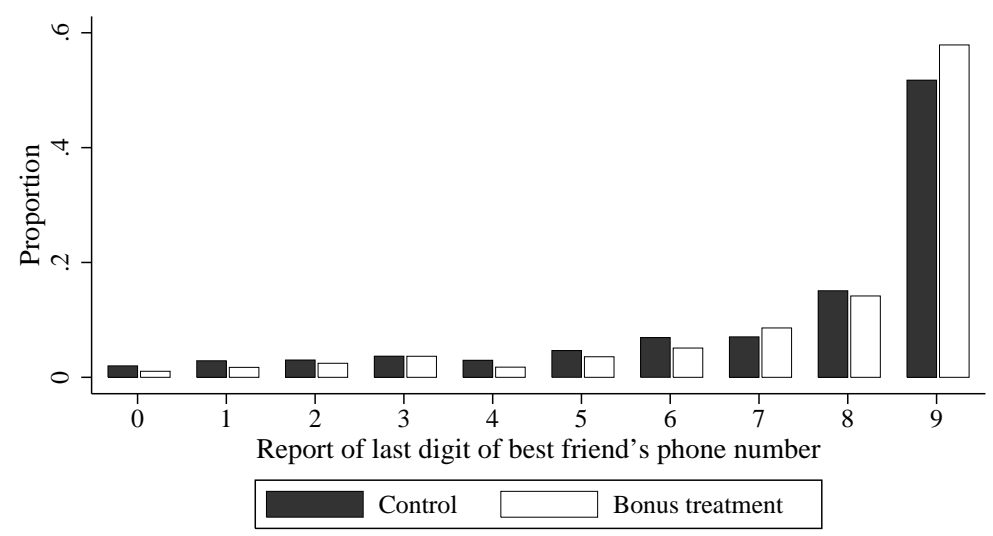

(a) Probability mass function.

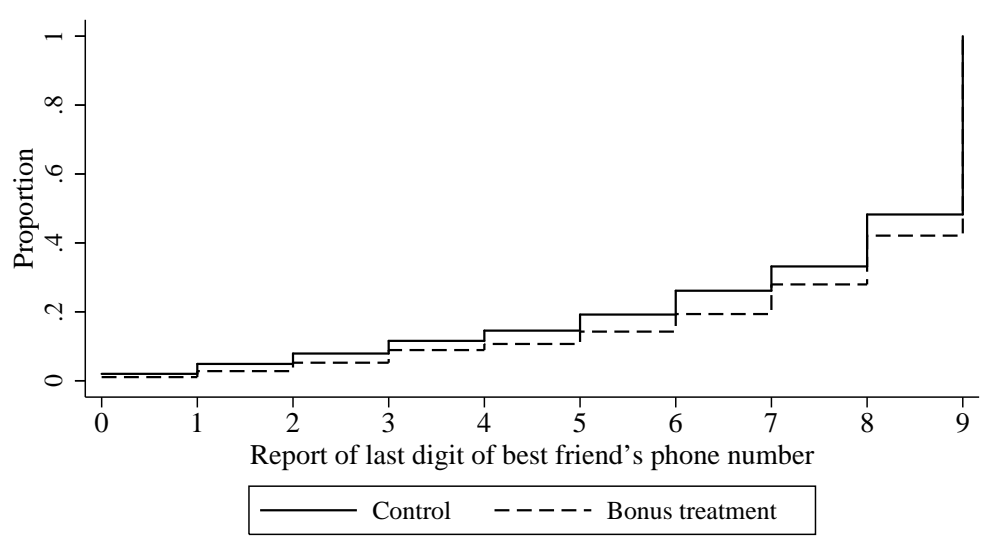

(b) Cumulative distribution function.

Figure 3: Effect of bonus treatment on distribution of reported number.

Notes: The distributions are for the 582 subjects who reported a number. The data are weighted as explained in the notes to Table 1.

\footnotetext{
${ }^{15}$ Other papers have found that productivity in the slider task can be influenced by a variety of factors, including the size of the incentives and the productivity of the first-mover in a sequential tournament (Gill and Prowse, 2012), and by whether a subject won or lost in a previous round with repeated competition (Gill and Prowse, 2011a).

${ }^{16}$ The impact of the bonus treatment on cheating does not depend on whether subjects were paid $£ 2$ (C1 and $\mathrm{T} 1)$ or $£ 8$ (C2 and T2). When we run the regressions in columns 1-4 of Table 1 for subjects in C1 and T1 only or for subjects in $\mathrm{C} 2$ and $\mathrm{T} 2$ only, the coefficients on the treatment dummy are positive in both cases, and do not vary significantly when comparing that for $\mathrm{C} 1$ and $\mathrm{T} 1$ subjects to that for T2 and $\mathrm{C} 2$ subjects ( $p$-values of 0.703 , $0.524,0.882$ and 0.916 for columns $1-4$, respectively).
} 
We can see visually the impact of the bonus treatment on cheating by inspecting the probability and cumulative distributions of the reported number in Figure 3. Figure 3(b) illustrates that the cumulative distribution of the reported number for subjects who have been exposed to the bonus treatment first-order stochastically dominates that for subjects exposed to the control. In Figure 3(a) we can see that about $55 \%$ of the subjects report 9, the number that maximizes earnings: a high but incomplete rate of cheating is consistent with the existing evidence on cheating more broadly (e.g., Fischbacher and Heusi, 2008). Our finding that males cheat more (positive coefficients on the male dummy in columns 2 and 4 of Table 1 , significant at the $1 \%$ level) also matches previous findings (Dreber and Johannesson, 2008; Conrads et al., 2011; Houser et al., 2011).

\subsection{Effect of receiving bonus on cheating and productivity}

Next, we focus on the causal effect of receiving the random bonus on cheating and productivity. In Section 3.1, we looked at whether subjects exposed to the bonus treatment change their behavior, compared to the control subjects. Here we want to discover, within the subjects exposed to the bonus treatment in stage 2 , whether those who received the random bonus (T2) change their behavior in stage 3 compared to those who did not receive the bonus (T1).

\begin{tabular}{|c|c|c|c|c|c|c|}
\hline \multirow[b]{3}{*}{$\begin{array}{l}\text { Received bonus } \\
\text { (T2) }\end{array}$} & \multicolumn{2}{|c|}{$\begin{array}{l}\text { Reported } \\
\text { number }\end{array}$} & \multicolumn{2}{|c|}{$\begin{array}{l}\text { Proportion of } \\
\text { reports } \geq 7\end{array}$} & \multicolumn{2}{|c|}{$\begin{array}{l}\text { Points score in } \\
\text { slider task }\end{array}$} \\
\hline & (1) & $(2)$ & $(3)$ & $(4)$ & $(5)$ & $(6)$ \\
\hline & $\begin{array}{l}0.070 \\
{[0.259]} \\
(0.787)\end{array}$ & $\begin{array}{l}0.098 \\
{[0.257]} \\
(0.703)\end{array}$ & $\begin{array}{l}-0.022 \\
{[0.048]} \\
(0.642)\end{array}$ & $\begin{array}{l}-0.018 \\
{[0.047]} \\
(0.705)\end{array}$ & $\begin{array}{l}2.499 \\
{[2.267]} \\
(0.271)\end{array}$ & $\begin{array}{l}2.615 \\
{[2.237]} \\
(0.243)\end{array}$ \\
\hline Male & $\begin{array}{l}- \\
- \\
-\end{array}$ & $\begin{array}{l}0.620^{* *} \\
{[0.264]} \\
(0.020)\end{array}$ & $\begin{array}{l}- \\
- \\
-\end{array}$ & $\begin{array}{l}0.093^{*} \\
{[0.048]} \\
(0.054)\end{array}$ & $\begin{array}{l}- \\
- \\
-\end{array}$ & $\begin{array}{l}5.872^{* * *} \\
{[2.244]} \\
(0.009)\end{array}$ \\
\hline Intercept & $\begin{array}{l}7.642^{* * *} \\
{[0.188]} \\
(0.000)\end{array}$ & $\begin{array}{l}7.290^{* * *} \\
{[0.252]} \\
(0.000)\end{array}$ & $\begin{array}{l}0.818^{* * *} \\
{[0.032]} \\
(0.000)\end{array}$ & $\begin{array}{l}0.765^{* * *} \\
{[0.045]} \\
(0.000)\end{array}$ & $\begin{array}{c}88.268^{* * *} \\
{[1.648]} \\
(0.000)\end{array}$ & $\begin{array}{c}85.010^{* * *} \\
{[1.898]} \\
(0.000)\end{array}$ \\
\hline Obs. & 280 & 280 & 280 & 280 & 306 & 306 \\
\hline
\end{tabular}

Notes: (i) ${ }^{* * *}$ and ${ }^{* * *}$ denote, respectively, significance at the $10 \%, 5 \%$ and $1 \%$ levels. Heteroskedasticityrobust standard errors are in brackets. 2-sided $p$-values are in parentheses. (ii) The first four columns include only the 280 subjects exposed to the bonus treatment $\mathrm{T}$ who reported a number, while the final two include all 306 subjects exposed to T.

Table 2: Effect of receiving bonus: OLS regressions.

Table 2 replicates the analysis of Table 1, but using only the subjects exposed to the bonus treatment and using the receipt of the random bonus (T2) as the treatment dummy. The 
results show that receiving the bonus has no statistically significant effect on either cheating or productivity. Receiving the bonus has a small positive effect on the average number reported, a small negative effect on the proportion of subjects reporting a 7 or higher, and a small positive effect on the average points score in the slider task, but none of the effects are close to being significant. ${ }^{17}$ The probability and cumulative distributions of the reported number in Figure 4 confirm visually the absence of any effect of receiving the bonus on cheating.

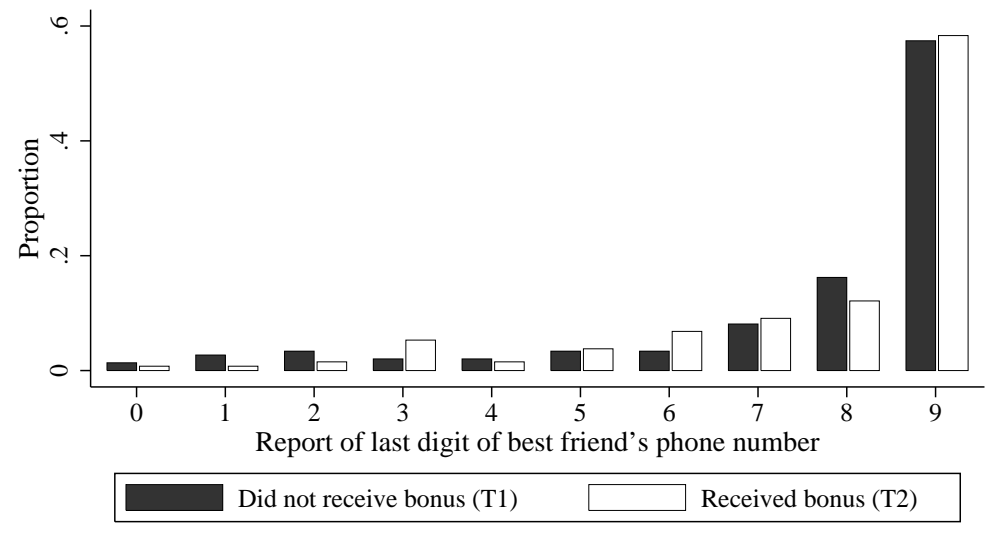

(a) Probability mass function.

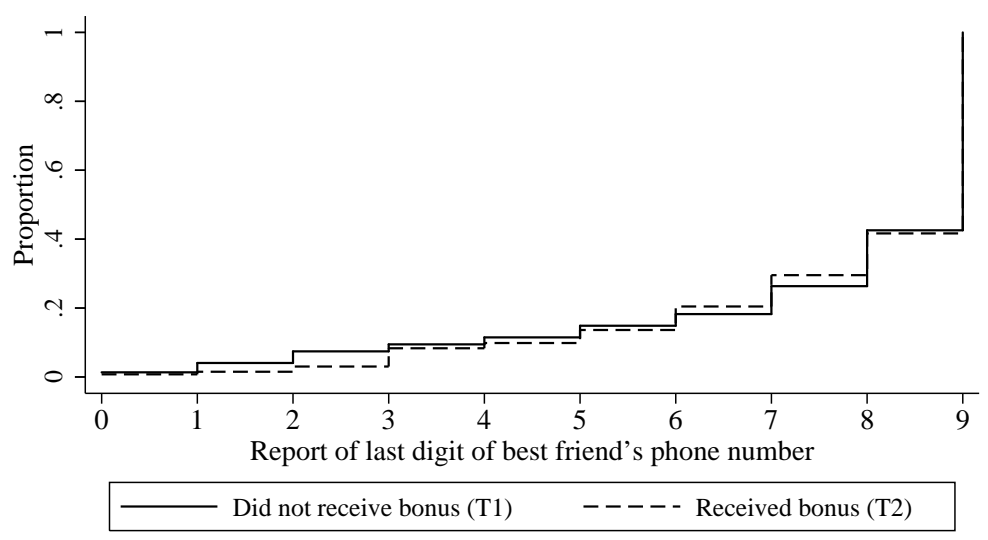

(b) Cumulative distribution function.

Figure 4: Effect of receiving bonus on distribution of reported number.

Note: The distributions are for the 280 subjects exposed to the bonus treatment $\mathrm{T}$ who reported a number.

In summary, the results presented above in Sections 3.1 and 3.2 reveal that the level of cheating depends on whether subjects were exposed to the bonus treatment, but not on whether they actually received the bonus. As discussed in Section 1.3, drawing on notions of procedural fairness and existing empirical evidence, a plausible interpretation is that subjects judge the random aspect of the bonus in the Treatment to be unjust, and reciprocate negatively in the

\footnotetext{
${ }^{17}$ We also find that income does not affect cheating when we compare the behavior of all the subjects who earned $£ 2(\mathrm{C} 1$ and $\mathrm{T} 1)$ to those who earned $£ 8$ (C2 and T2).
} 
form of more dishonesty.

\subsection{Relationship between cheating and productivity}

Finally, we want to see whether cheating and productivity in stage 3 are related. To do so, we regress (i) the report of the last digit of each subject's best friend's phone number and (ii) an indicator of the report being greater than or equal to 7 on each subject's points score in the slider task. Once again, we run the regressions with and without a male control. Table 3 shows that the more productive subjects also cheat more: a higher points score significantly increases the reported number (columns 1-2; 2-sided $p=0.050$ with a male control) and the probability that a subject reports a number greater than or equal to 7 (columns 3 -4; 2-sided $p=0.059$ with a male control). The regression coefficients imply that, on average, moving from the lowest points score of 32 to the highest points score of 159 increases the report by $22 \%$ and increases the probability of a subject reporting a 7 or higher by $43 \% .^{18}$

\begin{tabular}{|c|c|c|c|c|}
\hline \multirow[b]{3}{*}{$\begin{array}{l}\text { Points score in } \\
\text { slider task }\end{array}$} & \multicolumn{2}{|c|}{$\begin{array}{c}\text { Reported } \\
\text { number }\end{array}$} & \multicolumn{2}{|c|}{$\begin{array}{c}\text { Probability of } \\
\text { report } \geq 7\end{array}$} \\
\hline & (1) & $(2)$ & $(3)$ & (4) \\
\hline & $\begin{array}{l}0.011^{* *} \\
{[0.005]} \\
(0.017)\end{array}$ & $\begin{array}{l}0.009^{* *} \\
{[0.005]} \\
(0.050)\end{array}$ & $\begin{array}{l}0.002^{* *} \\
{[0.001]} \\
(0.019)\end{array}$ & $\begin{array}{c}0.002^{*} \\
{[0.001]} \\
(0.059)\end{array}$ \\
\hline Male & $\begin{array}{l}- \\
- \\
-\end{array}$ & $\begin{array}{l}0.461^{* *} \\
{[0.200]} \\
(0.022)\end{array}$ & $\begin{array}{l}- \\
- \\
-\end{array}$ & $\begin{array}{l}0.086^{* *} \\
{[0.036]} \\
(0.019)\end{array}$ \\
\hline Intercept & $\begin{array}{l}6.486^{* * *} \\
{[0.446]} \\
(0.000)\end{array}$ & $\begin{array}{l}6.393^{* * *} \\
{[0.444]} \\
(0.000)\end{array}$ & $\begin{array}{l}0.593^{* * *} \\
{[0.080]} \\
(0.000)\end{array}$ & $\begin{array}{l}0.576^{* * *} \\
{[0.080]} \\
(0.000)\end{array}$ \\
\hline Obs. & 582 & 582 & 582 & 582 \\
\hline
\end{tabular}

Notes: (i) ${ }^{*},{ }^{* *}$ and ${ }^{* * *}$ denote, respectively, significance at the $10 \%, 5 \%$ and $1 \%$ levels. Heteroskedasticityrobust standard errors are in brackets. 2-sided $p$-values are in parentheses. (ii) We include only the 582 subjects who reported a number. Table 6 in Appendix B shows that our results are robust to including all 641 subjects who completed the experiement, and so using money earned from the report as the dependent variable rather than the report itself. The effects are slightly larger in magnitude, but not quite as precisely estimated.

Table 3: Relationship between cheating and productivity: OLS regressions.

\footnotetext{
${ }^{18}$ The relationship between cheating and productivity does not depend on whether subjects were exposed to the bonus treatment $(\mathrm{T})$ or the control $(\mathrm{C})$, and nor does the relationship depend on whether subjects were paid $£ 2$ (C1 and $\mathrm{T} 1)$ or $£ 8$ (C2 and $\mathrm{T} 2)$. When we run the regressions in Table 3 for subjects in $\mathrm{C}$ only or for subjects in $\mathrm{T}$ only, the coefficients on the points score are positive in all cases, and do not vary significantly when comparing that for $\mathrm{C}$ subjects to that for T subjects ( $p$-values of $0.267,0.260,0.294$ and 0.291 for columns $1-4$, respectively). When we run the regressions for subjects in $\mathrm{C} 1$ and $\mathrm{T} 1$ only or for subjects in $\mathrm{C} 2$ and $\mathrm{T} 2$ only, the coefficients on the points score are positive in all cases, and do not vary significantly when comparing that for $\mathrm{C} 1$ and $\mathrm{T} 1$ subjects to that for T2 and C2 subjects ( $p$-values of $0.740,0.670,0.281$, and 0.241 for columns $1-4$, respectively).
} 
Our result that more productive workers cheat more is consistent with people who are more strongly motivated by money working harder in order to earn more and also being more tempted to cheat for personal gain. The result may also reflect that subjects' self-control is eroded by working on the real-effort task. Alternatively, hard-working subjects may have felt that they deserved more for their labor. Further discussion of these mechanisms can be found in Section 1.3.

\section{Conclusion}

Despite their importance, employee cheating and crime have received insufficient attention by economists. Our analysis contributes to a burgeoning literature that examines the interaction between compensation schemes and cheating in the workplace, and we are the first to investigate a link between productivity and dishonesty. Our findings suggest that workers perceive exposure to random bonuses as unfair, providing a justification for negative reciprocity in the form of increased cheating. Thus, bonus-based compensation may have important unintended sideeffects that have not been highlighted in the existing literature, which has instead focused on the incentive effects of bonuses. Complementary field evidence and replication of our novel experimental findings in laboratory studies would be of particular value to determine the degree to which our results extend to different work tasks and to bonus schemes used in practice.

\section{Appendix}

\section{A Experimental instructions}

Log In

You are being asked to take part in an experiment on economic decision-making. The experiment will last about 20 to 25 minutes. We are very grateful for your participation. You will be paid a participation fee of $£ 3$ for completing the experiment. You will also have the opportunity to earn additional money. Your earnings today will depend on your own actions and some element of chance. Further details will be provided during the experiment. You will be able to come to Room 3115 in Building 58 (Murray Building - Highfield Campus) between 9am and 6pm on Thursday 26 May or Wednesday 1 June to collect your payment for the experiment. You will be paid in cash. If you cannot come on one of these days, please do not participate. Please complete the experiment on a desktop or laptop computer. Tablet computers, iPads, iPhones etc. will not work properly. You must not press any of your browser buttons (e.g., stop, refresh, reload, back, forward) at any time. If you do so, you will exit the experiment and you will not be paid anything. Please do not use your keyboard: use only your mouse or touchpad. Once you log in to start the experiment, you must complete it in one go. If you leave the experiment, you cannot return and you will not be paid anything. You have the right to withdraw from the experiment 
at any time. If you withdraw from the experiment, you will not be paid anything. If you have a technical problem during the experiment please contact: jy2e08@ecs.soton.ac.uk. If you have forgotten your password, or for any other query, please contact: jy2e08@ecs.soton.ac.uk. If you wish to participate now, please enter your username and password below. [Box to enter previously provided username and password] Note, if you have trouble logging in using Firefox, please follow the troubleshoot [Web link]. Alternatively, you can use the Google Chrome browser or use a computer in the computing room at the Hartley Library.

\section{Instructions - General Overview}

You must not press any of your browser buttons (e.g., stop, refresh, reload, back, forward) at any time. If you do so, you will exit the experiment and you will not be paid anything. Please do not use your keyboard: use only your mouse or touchpad. The experiment will consist of 3 stages. At the start of each stage, you will receive instructions about that stage. What you do in stage 1 will not affect what happens in stages 2 and 3 , and what you do in stage 2 will not affect what happens in stage 3 . As is the case in all economics experiments, we will not deceive you in any way during the experiment. In particular, this means that we will not give you any false information at any time during the experiment. ["Proceed" button] Button will enable in 50 seconds. Once the button is enabled, please press it to proceed when you are ready.

\section{Instructions - The Task}

In each stage you will have the opportunity to attempt a computerised task. The task will consist of a screen with a large number of sliders. Each slider is initially positioned at 0 and can be moved as far as 100. Each slider has a number to its right showing its current position. You can use your mouse or touchpad in any way you like to move each slider. You can readjust the position of each slider as many times as you wish. All the sliders will be on one page, but you may need to scroll down the page to see them all. You will receive 2 points for each slider that you position at exactly 50. You will receive 1 point for each slider that you position at exactly 49 or 51 . Your "points score" in the task will be your total number of points. During the task, a number of pieces of information will appear at the top of your screen, including the time remaining and your points score in the task so far. ["Proceed" button] Button will enable in 90 seconds

\section{Stage 1 out of 3: Instructions}

In stage 1 you will have 2 minutes to practice the task. The purpose of this stage is purely to allow you to practice the task. Therefore, you will not be paid for this stage. ["Start Practice" button] Button will enable in 20 seconds

\section{Stage 2 out of 3: Instructions}

To complete stage 2 you must reach a points score of 40 in the task within 10 minutes. As soon as you reach a points score of 40 you will proceed immediately to the next screen. $\{\mathrm{C} 1$ : You will be paid $£ 2$ for completing stage 2 . $\{$ C 2 : You will be paid $£ 8$ for completing stage 2 . $\{\mathrm{T} 1$ 
and T2: You will be paid $£ 2$ for completing stage 2. There is also a $50 \%$ chance that you will earn a bonus of an additional $£ 6$ for completing stage 2 . If you earn the bonus, you will thus be paid a total of $£ 8=£ 2+£ 6$ for completing the stage. A computer will use a random number generator to decide randomly whether or not you have earned the bonus for completing stage 2 . You will find out whether you have earned the bonus only after completing the stage.\} If you fail to complete stage 2 within 10 minutes you will leave the experiment automatically and you will not be paid anything. ["Start Stage 2" button] Button will enable in 90 seconds

Stage 2 out of 3: Summary of payment

$\{\mathrm{C} 1$ : Your payment for completing stage 2 is $£ 2\}.\{\mathrm{C} 2$ : Your payment for completing stage 2 is £8.\} \{T1: Remember that there was a $50 \%$ chance that you would earn a bonus of $£ 6$ for completing stage 2. You did not earn the bonus. Your payment for completing stage 2 is $£ 2\}.\{\mathrm{T} 2$ : Remember that there was a $50 \%$ chance that you would earn a bonus of $£ 6$ for completing stage 2. You did earn the bonus. Your payment for completing stage 2 is $£ 8$.\} ["Proceed" button] Button will enable in 45 seconds

Stage 3 out of 3 : Instructions

In stage 3 you will have the opportunity to attempt the task for a period of 5 minutes. You will be paid according to your points score at the end of the 5 minutes. In particular, you will be paid 5 pence for every point you score. You will also be asked to report the last digit of your best friend's phone number, i.e., $0,1,2,3,4,5,6,7,8$ or 9 . In addition to the payment for your points score in the task, you will be paid an amount in pounds equal to the number that you report. Therefore, for every increase of 1 in the number that you report, your payment for stage 3 will go up by $£ 1$. You can report the last digit of your best friend's phone number at any time during the 5 minutes for this stage. If you make a mistake, you can change your report during the 5 minutes. At the end of the 5 minutes your report will be final. If you do not know or cannot find your best friend's phone number, please select the "don't know" option. Your payment for stage 3 will then depend only on your points score in the task. ["Start Stage 3" button] Button will enable in 90 seconds

\section{B Robustness}

We collect here three tables that are referred to in the notes to Tables 1 and 3 as providing robustness checks. 


\begin{tabular}{|c|c|c|c|c|c|c|}
\hline \multirow[b]{3}{*}{$\begin{array}{l}\text { Treated } \\
\quad(\mathrm{T})\end{array}$} & \multicolumn{2}{|c|}{$\begin{array}{c}\text { Reported } \\
\text { number }\end{array}$} & \multicolumn{2}{|c|}{$\begin{array}{c}\text { Proportion of } \\
\text { reports } \geq 7\end{array}$} & \multicolumn{2}{|c|}{$\begin{array}{l}\text { Points score in } \\
\text { slider task }\end{array}$} \\
\hline & $(1)$ & (2) & $(3)$ & $(4)$ & (5) & $(6)$ \\
\hline & $\begin{array}{l}0.354^{*} \\
{[0.192]} \\
(0.066)\end{array}$ & $\begin{array}{l}0.364^{*} \\
{[0.191]} \\
(0.057)\end{array}$ & $\begin{array}{l}0.069^{* *} \\
{[0.035]} \\
(0.048)\end{array}$ & $\begin{array}{l}0.071^{* *} \\
{[0.034]} \\
(0.041)\end{array}$ & $\begin{array}{l}-0.160 \\
{[1.667]} \\
(0.924)\end{array}$ & $\begin{array}{l}-0.114 \\
{[1.645]} \\
(0.945)\end{array}$ \\
\hline Male & $\begin{array}{l}- \\
- \\
-\end{array}$ & $\begin{array}{l}0.535^{* * *} \\
{[0.195]} \\
(0.006)\end{array}$ & $\begin{array}{l}- \\
- \\
-\end{array}$ & $\begin{array}{l}0.099^{* * *} \\
{[0.035]} \\
(0.005)\end{array}$ & $\begin{array}{l}- \\
- \\
-\end{array}$ & $\begin{array}{l}7.031^{* * *} \\
{[1.638]} \\
(0.000)\end{array}$ \\
\hline Intercept & $\begin{array}{l}7.321^{\text {*** }} \\
{[0.141]} \\
(0.000)\end{array}$ & $\begin{array}{l}7.018^{* * *} \\
{[0.180]} \\
(0.000)\end{array}$ & $\begin{array}{l}0.738^{* * *} \\
{[0.025]} \\
(0.000)\end{array}$ & $\begin{array}{l}0.682^{* * *} \\
{[0.034]} \\
(0.000)\end{array}$ & $\begin{array}{c}89.588^{* * *} \\
{[1.214]} \\
(0.000)\end{array}$ & $\begin{array}{c}85.706^{* * *} \\
{[1.418]} \\
(0.000)\end{array}$ \\
\hline Obs. & 582 & 582 & 582 & 582 & 641 & 641 \\
\hline
\end{tabular}

Notes: All results are from OLS regressions. ${ }^{*},{ }^{* *}$ and ${ }^{* * *}$ denote, respectively, significance at the $10 \%$, $5 \%$ and $1 \%$ levels. Heteroskedasticity-robust standard errors are in brackets. 2-sided $p$-values are in parentheses.

Table 4: Robustness (Table 1): unweighted data.

\begin{tabular}{|c|c|c|c|c|}
\hline & $\begin{array}{l}\text { Earnin } \\
\text { report (ir }\end{array}$ & $\begin{array}{l}\text { from } \\
\text { ounds) }\end{array}$ & $\begin{array}{l}\text { Proportion } \\
\text { from rep }\end{array}$ & $\begin{array}{l}\text { f earnings } \\
\mathrm{t} \geq £ 7\end{array}$ \\
\hline & $(1)$ & (2) & (3) & (4) \\
\hline Treated & $0.413^{*}$ & $0.414^{*}$ & $0.071^{* *}$ & $0.071^{* *}$ \\
\hline$(\mathrm{T})$ & [0.243] & {$[0.242]$} & {$[0.036]$} & {$[0.036]$} \\
\hline & (0.089) & (0.087) & $(0.050)$ & $(0.049)$ \\
\hline Male & - & $0.682^{* * *}$ & - & $0.111^{* * *}$ \\
\hline & - & {$[0.245]$} & - & {$[0.036]$} \\
\hline & - & $(0.006)$ & - & $(0.003)$ \\
\hline Intercept & $6.619^{* * *}$ & $6.247^{* * *}$ & $0.668^{* * *}$ & $0.607^{* * *}$ \\
\hline & {$[0.174]$} & {$[0.226]$} & {$[0.026]$} & {$[0.034]$} \\
\hline & $(0.000)$ & $(0.000)$ & $(0.000)$ & $(0.000)$ \\
\hline Obs. & 641 & 641 & 641 & 641 \\
\hline
\end{tabular}

Notes: (i) All results are from OLS regressions. ${ }^{*},{ }^{* *}$ and ${ }^{* * *}$ denote, respectively, significance at the $10 \%, 5 \%$ and $1 \%$ levels. Heteroskedasticity-robust standard errors are in brackets. 2-sided $p$-values are in parentheses. (ii) Since we include the subjects who did not report a number, the dependent variable is money earned from the report rather than the report itself.

Table 5: Robustness (columns 1-4 of Table 1): all 641 subjects. 


\begin{tabular}{|c|c|c|c|c|}
\hline \multirow{5}{*}{$\begin{array}{l}\text { Points score in } \\
\text { slider task }\end{array}$} & \multicolumn{2}{|c|}{$\begin{array}{l}\text { Earnings from } \\
\text { report (in pounds) }\end{array}$} & \multicolumn{2}{|c|}{$\begin{array}{l}\text { Probability of earnings } \\
\text { from report } \geq £ 7\end{array}$} \\
\hline & $(1)$ & $(2)$ & $(3)$ & $(4)$ \\
\hline & $0.012^{* *}$ & $0.010^{*}$ & $0.002^{* *}$ & $0.002^{*}$ \\
\hline & {$[0.006]$} & {$[0.006]$} & {$[0.001]$} & {$[0.001]$} \\
\hline & $(0.035)$ & $(0.093)$ & $(0.020)$ & $(0.064)$ \\
\hline \multirow[t]{3}{*}{ Male } & - & $0.614^{* *}$ & - & $0.098^{* * *}$ \\
\hline & - & {$[0.252]$} & - & {$[0.037]$} \\
\hline & - & $(0.015)$ & - & (0.009) \\
\hline \multirow[t]{3}{*}{ Intercept } & $5.684^{* * *}$ & $5.561^{* * *}$ & $0.518^{* * *}$ & $0.498^{* * *}$ \\
\hline & {$[0.554]$} & {$[0.551]$} & {$[0.081]$} & {$[0.081]$} \\
\hline & $(0.000)$ & $(0.000)$ & $(0.000)$ & $(0.000)$ \\
\hline Obs. & 641 & 641 & 641 & 641 \\
\hline
\end{tabular}

Notes: (i) All results are from OLS regressions. ${ }^{*},{ }^{* *}$ and ${ }^{* * *}$ denote, respectively, significance at the $10 \%, 5 \%$ and $1 \%$ levels. Heteroskedasticity-robust standard errors are in brackets. 2-sided $p$-values are in parentheses. (ii) Since we include the subjects who did not report a number, the dependent variable is money earned from the report rather than the report itself.

Table 6: Robustness (Table 3): all 641 subjects.

\section{References}

Abdolmohammadi, M.J. and Baker, C.R. (2007). The relationship between moral reasoning and plagiarism in accounting courses: A replication study. Issues in Accounting Education, 22(1): $45-55$

Abeler, J., Becker, A., and Falk, A. (2012). Truth-telling - A representative assessment. Mimeo, University of Oxford

ACFE (2012). Report to the Nations on Occupational Fraud and Abuse: 2012 Global Fraud Study. Association of Certified Fraud Examiners, TX: Austin

Bertrand, M. and Mullainathan, S. (2001). Are CEOs rewarded for luck? The ones without principals are. Quarterly Journal of Economics, 116(3): 901-932

Bhattacherjee, D. (2005). The effects of group incentives in an Indian firm: Evidence from payroll data. Labour, 19(1): 147-173

Bonein, A. and Denant-Boemont, L. (2011). Temptation, commitment and peer pressure: A laboratory experiment. Mimeo, University of Rennes

Bucciol, A. and Piovesan, M. (2011). Luck or cheating? A field experiment on honesty with children. Journal of Economic Psychology, 32(1): 73-78

Burns, N. and Kedia, S. (2006). The impact of performance-based compensation on misreporting. Journal of Financial Economics, 79(1): 35-67

Cadsby, C.B., Song, F., and Tapon, F. (2010). Are you paying your employees to cheat? An experimental investigation. B.E. Journal of Economic Analysis $\mathscr{E}$ Policy, 10(1): Article 35

Cettolin, E. and Riedl, A. (2011). Fairness and uncertainty. Mimeo, Maastricht University

Charness, G. and Dufwenberg, M. (2006). Promises and partnership. Econometrica, 74(6): 1579-1601

Charness, G. and Garoupa, N. (2000). Reputation, honesty, and efficiency with insider information: An experiment. Journal of Economics \& Management Strategy, 9(3): 425-451

Charness, G. and Levine, D.I. (2007). Intention and stochastic outcomes: An experimental study. Economic Journal, 117(522): 1051-1072

Chen, C.X. and Sandino, T. (forthcoming). Can wages buy honesty? The relationship 
between relative wages and employee theft. Journal of Accounting Research

Chow, C.W., Hirst, M.K., and Shields, M.D. (1994). Motivating truthful subordinate reporting: An experimental investigation in a two-subordinate context. Contemporary Accounting Research, 10(2): 699-720

Cojoc, D. and Stoian, A. (2012). Dishonesty and charitable behavior. Mimeo, University of Iowa

Conrads, J., Irlenbusch, B., Rilke, R.M., and Walkowitz, G. (2011). Lying and team incentives. IZA Discussion Paper 5968

Core, J.E. and Guay, W.R. (2001). Stock option plans for non-executive employees. Journal of Financial Economics, 61(2): 253-287

Coricelli, G., Joffily, M., Montmarquette, C., and Villeval, M.C. (2010). Cheating, emotions, and rationality: An experiment on tax evasion. Experimental Economics, 13(2): $226-247$

Croson, R., Boles, T., and Murnighan, J. (2003). Cheap talk in bargaining experiments: lying and threats in ultimatum games. Journal of Economic Behavior \& Organization, 51(2): 143-159

Curry, P.A. and Mongrain, S. (2009). Deterrence in rank-order tournaments. Review of Law \& Economics, 5(1): 723-740

Dickens, W.T., Katz, L.F., Lang, K., and Summers, L.H. (1989). Employee crime and the monitoring puzzle. Journal of Labor Economics, 7(3): 331-347

Djawadi, B.M. and Fahr, R. (2012). The impact of tax knowledge and budget spending influence on tax compliance. Mimeo, University of Paderborn

Dreber, A. and Johannesson, M. (2008). Gender differences in deception. Economics Letters, 99(1): 197-199

Eacret, N.D., Lafferty, N.C., and Jhunjhunwala, T. (2011). When is inequality fair? Mimeo, University of Texas at Dallas

Efendi, J., Srivastava, A., and Swanson, E. (2007). Why do corporate managers misstate financial statements? The role of option compensation and other factors. Journal of Financial Economics, 85(3): 667-708

Eisenberger, R. and Shank, D.M. (1985). Personal work ethic and effort training affect cheating. Journal of Personality and Social Psychology, 49(2): 520-528

Eisenkopf, G., Gurtoviy, R., and Utikal, V. (2011). Size matters - when it comes to lies. IAAEG Discussion Paper 02/2011

Evans III, J.H., Hannan, R.L., Krishnan, R., and Moser, D.V. (2001). Honesty in managerial reporting. Accounting Review, 76(4): 537-559

Fischbacher, U. and Heusi, F. (2008). Lies in disguise: An experimental study on cheating. TWI Research Paper 40

Fischbacher, U. and Utikal, V. (2011). Disadvantageous lies. TWI Research Paper 71

Gill, D. and Prowse, V. (2011a). Gender differences and dynamics in competition: The role of luck. Department of Economics Discussion Paper 564, University of Oxford

Gill, D. and Prowse, V. (2011b). A novel computerized real effort task based on sliders. IZA Discussion Paper 5801

Gill, D. and Prowse, V. (2012). A structural analysis of disappointment aversion in a real effort competition. American Economic Review, 102(1): 469-503

Gilpatric, S.M. (2011). Cheating in contests. Economic Inquiry, 49(4): 1042-1053

Gino, F., Schweitzer, M.E., Mead, N.L., and Ariely, D. (2011). Unable to resist temptation: How self-control depletion promotes unethical behavior. Organizational Behavior and Human Decision Processes, 115(2): 191-203

Gneezy, U. (2005). Deception: The role of consequences. American Economic Review, 95(1): 384-394

Greenberg, J. (1990). Employee theft as a reaction to underpayment inequity: The hidden cost of pay cuts. Journal of Applied Psychology, 75(5): 561-568

Grover, S.L. (1993). Lying, deceit, and subterfuge: A model of dishonesty in the workplace. Organization Science, 478-495

Hall, B.J. and Liebman, J.B. (1998). Are CEOs really paid like bureaucrats? Quarterly Journal of Economics, 113(3): 653-691

Hammermann, A., Mohnen, A., and Nieken, P. (2011). Whom to choose as a team mate? A lab experiment about in-group favouritism. IZA Discussion Paper 6286

Hansen, D. (1997). Worker performance and group incentives: A case study. Industrial and Labor Relations Review, 51(1): 37-49

Hao, L. and Houser, D. (2011). Honest lies. ICES Discussion Paper 2011-03, George Mason 
University

Hetzel, S. (2010). The impact of financial incentives on individual performance: An experimental approach. Diplomarbeit, University of Mannheim

Houser, D., Vetter, S., and Winter, J. (2011). Fairness and cheating. ICES Discussion Paper 2011-01, George Mason University

Jacob, B.A. and Levitt, S.D. (2003). Rotten apples: An investigation of the prevalence and predictors of teacher cheating. Quarterly Journal of Economics, 118(3): 843-877

Kaur, S., Kremer, M., and Mullainathan, S. (2011). Self-control at work. Mimeo, Harvard University

Knez, M. and Simester, D. (2001). Firm-wide incentives and mutual monitoring at Continental Airlines. Journal of Labor Economics, 19(4): 743-772

Konow, J. (2003). Which is the fairest one of all? A positive analysis of justice theories. Journal of economic literature, 41(4): 1188-1239

Lammers, J., Stapel, D., and Galinsky, A. (2010). Power increases hypocrisy. Psychological Science, 21(5): 737-744

Lazear, E.P. and Rosen, S. (1981). Rank-order tournaments as optimum labor contracts. Journal of Political Economy, 89(5): 841-864

Lewis, A., Bardis, A., Flint, C., Mason, C., Smith, N., Tickle, C., and Zinser, J. (2012). Drawing the line somewhere: An experimental study of moral compromise. Journal of Economic Psychology, 33(4): 718-725

Lundquist, T., Ellingsen, T., Gribbe, E., and Johannesson, M. (2009). The aversion to lying. Journal of Economic Behavior $\&$ Organization, 70(1-2): 81-92

Matuszewski, L.J. (2010). Honesty in managerial reporting: Is it affected by perceptions of horizontal equity? Journal of Management Accounting Research, 22(1): 233-250

Mazar, N., Amir, O., and Ariely, D. (2008). The dishonesty of honest people: A theory of self-concept maintenance. Journal of Marketing Research, 45(6): 633-644

Mead, N.L., Baumeister, R.F., Gino, F., Schweitzer, M.E., and Ariely, D. (2009). Too tired to tell the truth: Self-control resource depletion and dishonesty. Journal of Experimental Social Psychology, 45(3): 594-597

Moers, F. (2005). Discretion and bias in performance evaluation: the impact of diversity and subjectivity. Accounting, Organizations and Society, 30(1): 67-80

Monahan, J. (2012). We're all Lockeans now: A test of the prevalence of just-desert considerations in a dictator game experiment. M.Phil. Thesis, University of Oxford

Nagin, D.S., Rebitzer, J.B., Sanders, S., and Taylor, L.J. (2002). Monitoring, motivation, and management: The determinants of opportunistic behavior in a field experiment. American Economic Review, 92(4): 850-873

Oyer, P. (2004). Why do firms use incentives that have no incentive effects? Journal of Finance, 59(4): 1619-1650

Oyer, P. and Schaefer, S. (2005). Why do some firms give stock options to all employees?: An empirical examination of alternative theories. Journal of financial Economics, 76(1): 99-133

Riener, G. and Wiederhold, S. (2011). On social identity, subjective expectations, and the costs of control. Jena Economic Research Paper 2011-035

Schwieren, C. and Weichselbaumer, D. (2010). Does competition enhance performance or cheating? A laboratory experiment. Journal of Economic Psychology, 31(3): 241-253

Shalvi, S., Dana, J., Handgraaf, M.J.J., and De Dreu, C.K.W. (2011). Justified ethicality: Observing desired counterfactuals modifies ethical perceptions and behavior. Organizational Behavior and Human Decision Processes, 115(2): 181-190

Shalvi, S., Eldar, O., and Bereby-Meyer, Y. (forthcoming). Honesty requires time (and lack of justifications). Psychological Science

Suri, S., Goldstein, D.G., and Mason, W.A. (2011). Honesty in an online labor market. Human Computation: Papers from the 2011 AAAI Workshop (WS-11-11)

Trautmann, S.T. (2009). A tractable model of process fairness under risk. Journal of Economic Psychology, 30(5): 803-813

Waller, W.S. and Bishop, R.A. (1990). An experimental study of incentive pay schemes, communication, and intrafirm resource allocation. Accounting Review, 65(4): 812-836

Wang, J.T., Spezio, M., and Camerer, C.F. (2010). Pinocchio's pupil: Using eyetracking and pupil dilation to understand truth telling and deception in sender-receiver games. American Economic Review, 100(3): 984-1007

Zhang, Y. (2008). The effects of perceived fairness and communication on honesty and collusion in a multi-agent setting. Accounting Review, 83(4): 1125-1146 